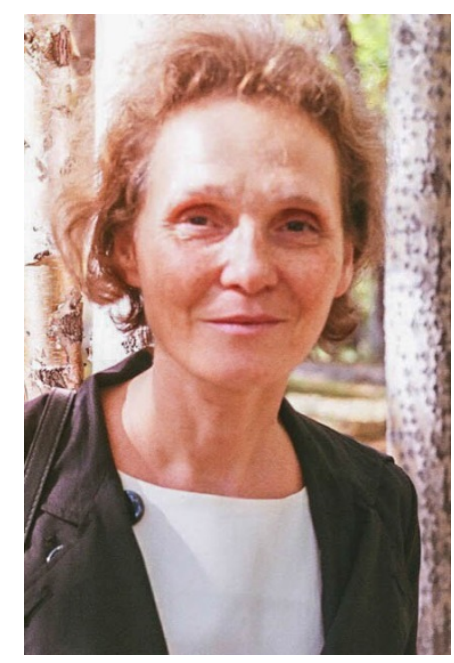

Alina Pavlovna Ivanova, Candidate of Architecture, Associate Professor of Department of architectural environment design of the Pacific State University Khabarovsk, Russia iva.nova@mail.ru

DOI 10.31554/978-5-7925-0571-1-2019-2-178-183

\title{
FAR EASTERN FOLK ARCHITECTURE: CITIES AND SUBURBIA
}

As a working hypothesis it is suggested that the local "folk" architecture reproduces the primary cultural matrix laid down in the frontier era. To understand the modern architectural landscape of the far Eastern cities (Blagoveshchensk, Ussuriysk, Khabarovsk, Petropavlovsk-Kamchatsky, Yuzhno-Sakhalinsk, Vladivostok), it is necessary to return to the era of the frontier and identify the main architectural scenes associated with these locations. The analysis of the historical architecture typical for each of the listed cities is given, the iconic objects which served as prototypes to the modern vernacular are revealed. The features of the "folk" architecture characteristic of each particular city are considered based on the material collected in the expeditions.

Keywords: suburbia, frontier architecture, Far Eastern folk architecture.

The study was funded by the RFBR as part of research project No. 18012-00537. The report written at the end of the summer field season 2019 is devoted to the comparison of the vernacular of the far Eastern cities. As a working hypothesis it is suggested that the local "folk" architecture reproduces the primary cultural matrix laid down in the frontier era. 
Specification of the proposed terms. "Folk" architecture is a conditional category that includes residential and commercial buildings created without participation of the state, development and large business; "folk" architecture is considered as organic continuation of frontier architecture.

Source base of the study. In addition to systematic photofixing of objects, personal observations, surveys and "oral memoirs", we relied on the corpus of frontier Chronicles-diaries, travelogues, letters and memoirs of the late XIX - early XX centuries. [Arseniev 1926; Arseniev 1912], [Kaufman 1901; Kaufman 1905], [Yankovsky 2012; Prey 2011], as well as monographs of local historians [ Zueva; Viter 1997; Samarin 2018].

Features of formation of the far Eastern cultural landscape. Far Eastern cities founded in the XIX - the first third of the XX century remained lonely strips, islands of civilization, lost in the vast desert spaces. They are selfcontained enclaves, where the architecture of the first stage of colonization is reproduced again and again. The theme of reception of frontier architecture in modern suburbia was revealed in the textbook [Ivanova 2018]. The main difference between far eastern cities is due to the geographical location and the way of colonisation. The key points of the continental colonisation: Blagoveshchensk, Khabarovsk, Ussuriysk-Nikolsky. The historical centers of these cities have a rectangular layout, typical of colonial urban planning and successfully used by the Roman legions. Yuzhno-Sakhalinsk, lying in a fertile valley, also preserved the rigid regular structure laid down by the Japanese during the Karafuto period.

The key points of marine colonization are located on a pronounced relief and have a complex picturesque layout. While in the continental cities villages and outskirts are spreading along the main transport links horizontally, in Petropavlovsk and Vladivostok "vertical suburbia".are actively developing.

The reception of architecture of the frontier in modern vernacular. To understand modern architectual landscape of far eastern cities it is necessary to go back the frontier era. Blagoveshchensk owes its prosperity to the «gold rush». In the first decade of the XX century the city experienced a surge of merchant Baroque, the apotheosis of which was the construction of a huge Churin Palace, which, though, remained a lonely architectural excesses, but the blagoveshchensk mainstream turned towards the usual red brick garrison architecture with a distinct Gothic accent. The flagship of this "patriotic" direction was the majestic German trading house " Kunst and Albers». 
Though, with the exception of the three main streets running parallel to the Amur embankment and built up with merchant mansions with a garrison on the left flank, Blagoveshchensk was (and it is still) a well-planned wooden one-story city. The main residential unit was a square hut with a low fourpitched roof. The well-preserved housing stock prevented the appearance of significant suburbs in Blagoveshchensk. The city residents continue to live in inherited huts. The commercial vernacular imitates the red-brick architecture of the frontier, quoting the character of the decor and the spatial compositions of the facades. Despite the fact that the Haihe is growing rapidly directly opposite Blagoveshchensk on the Chinese Bank of the Amur river, the influence of the Chinese construction industry on the architectural landscape of the Russian city is less catastrophic than one might expect. Blagoveshchensk pupated in its legend of the "Golden age" and successfully exploits the well-preserved historical environment of a cozy low-rise merchant city. The middle class invests in real estate on the Chinese side - it is considered more profitable and reliable, so the old housing stock is not subjected to the usual "modernization".

A significant array of one-storey residential buildings (little Russian mazanka) survived in Ussuriysk-Nikolsky, founded in 1868 near the Chinese border. The Russian garrison was located in the old Jurchen fortress, a military town of red-brick barracks grew up around it, and officers' wings stretched along Lermontov street. The whole structure has come almost unchanged to the present day. The traditional placement of the district headquarters in Ussuriysk and the presence of a wealthy layer of customers with a conservative aesthetic program led to the formation of extensive suburbia, entirely built up with huge brick palazzos of garrison architecture. The extreme conservatism of the aesthetic program of the inhabitants of the Ussuri suburbs led to the creation of the worst kind of environment - highly class, closed, monotonous and unfriendly.

Khabarovsk, founded as a railway settlement serving the construction of a bridge across the Amur, quickly became an important administrative center and headquarters of the district, that inevitably led to the formation of an architectural landscape similar to the Ussuri (a two-story brick mansion, as a mandatory attribute of socialization). In recent years, Khabarovsk has been the center of a new resettlement movement - the city receives a significant number of migrants, who immediately begin to build a vernacular familiar to the Central Asian and Transcaucasian region. Khabarovsk 
suburbia lose the homogeneous character accompanying them since the late 1990s, and, as a reaction to the "new multiculturalism", the "red-brick Renaissance" is gathering pace». Until 2014, the basis of suburbia were castles and forts, but today there are whole blocks of new "red barracks - 2-3-5storey commercial buildings in the "historical Khabarovsk style", as these simulacra are positioned in the real estate market.

Let us move from the continental centers of colonization to the sea. The oldest far Eastern city - Petropavlovsk-Kamchatsky (the first fort was founded in 1740) amazes by the almost complete absence of brick architecture, which forms the basis of the architectural landscape of Khabarovsk, Blagoveshchensk, Ussuriysk and Vladivostok. But in Petropavlovsk the unique wooden architecture has remained which has formed "cultural code" of citizens and served as a source of inspiration for the linear suburbia stretching from Petropavlovsk deep into Peninsula to Elizovo where the climate is much softer. Since the 2010s, successful replicants have begun to appear in the city, almost completely imitating historical analogues. Wooden frame architecture became the basis of suburban landscapes and vertical suburbia of Petropavlovsk. The local vernacular is characterized by original dimensional compositions, intricate forms of roofs, giving buildings expressive silhouettes. Asceticism of decor is compensated by boldness of constructive decisions-abundance of terraces, verandas, console takeouts and so forth.

Sakhalin is an amazing experiment in double cultural transcoding. Russian island which was half transferred to the Japanese in 1904 and returned again to the Russians in 1945 [Samarin 2015]. Several generations of Soviet citizens grew up in Japanese "paper" houses, and this "cultural code" leaves a specific imprint on the local vernacular. Modern private residential development of Yuzhno-Sakhalinsk is monochrome and it is almost completely devoid of not only specific historical allusions, but also simple decor. The extremely laconic volumetric and spatial solutions of cottages (a cube under a four-pitched roof), the elusive strangeness of proportions, sizes and outlines of window openings - all this makes the Sakhalin suburbia completely unlike other far Eastern cities.

The main factor that shaped the architectural landscape of Vladivostok was a free port and unprecedented for the Russian Empire, the multiethnicity and multiculturalism of the city. The fragmentary historical center, built by Germans, Americans, French and Polish, allowed Vladivostok to 
position itself in the market of the South-Eastern tourism industry as a "real European city". Eclecticism and romanticism, highly inherent in the historical architectural landscape of Vladivostok, is reproduced in the commercial vernacular again and again ("coastal architecture"), the suburbs strike with fantastic castles, but the brick is confidently replaced by the architecture of the log house, as more "historical", "authentic", "Russian", and, therefore, more attractive for tourists from Southeast Asia.

Conclusion. The main types of development of the colonized territories were traditionally forts (garrisons) and trading posts; forts symbolized the state idea, trading posts - private initiative. According to the author, updating the historical heritage of colonization, like any heroic narrative may have compelling commercial perspectives, and the reconstruction of some objects and fragments of building 1860-1930-ies will have a beneficial effect on the appearance of the post-Soviet far Eastern settlements.

\section{References and sources}

Arsenyev V. K. V debryakh Usuriyskogo kraya [In the wilds of the Ussuri region] // - Vladivostok: Knizhnoe delo [Book matter]. - 1926. - 464 p.

Arsenyev V. K. Kratky voenno-geographichesky statistichesky ocherk Ussuriyskogo kraya 1901-1911 [Brief military-geographical and military-statistical essay of the Ussuri region 1901-1911]. - Khabarovsk: Tipographiya Shtaba Priamurskogo voennogo okruga [Printing house of the Amur military district headquartes]. - 1912. $-335 \mathrm{p}$.

Viter I. V. Khronika stroitelstva goroda Petropavlovska (1740-1923) [Chronicle of the construction of the Petropavlovsk city (1740-1923)]. - PetropavlovskKamchatsky: SETO-ST, 1997. - 112 p.

Zueva N. S., Lynsha O. B. Dorevolutsionny Ussuriysk: formirovanie arkhitekturnoplanirovochnoy structury, toponimii i obraza goroda [Pre-revolutionary Ussuriysk: formation of architectural and planning structure, toponymy and image of the city]. - Ussuriysk: DVFU [Publishing house of the University (branch in Ussuriysk)], 2012. - 92 p.

Ivanova A. P. Gorodskiye prostranstva: predmestya i dorogi [Urban spaces: suburbs and roads]. Vladivostok and Khabarovsk, 2015-2018. - Khabarovsk: Izd-vo [Publishing house of the Pacific State University], 2018. - 244 p.

Kaufman A. A. Materialy po voprosu o kolonizatsionnoy vmestimosti Priamurskogo kraya [Materials on the colonization capacity of the Amur region]. - SPb.: Tipographiya V. F. Kirshbauma [W. F. Kirschbaum printing house], 1901. - 304 p.

Kaufman A. A. Po novym mestam: ocherki I puteviye zametki [On new places: essays and travel notes]. 1901-1903. SPb.: Obshchestvennaya polza [Public benefit], 1905. - $353 \mathrm{p}$. 
Prey L. E. Pisma iz Vladivistoka [The letters from Vladivostok] 1894-1930. Vladivostok: Rubezh [Milestone], 2011. - 464 p.

Samarin I. A. Pamyatniki istorii i kultury perioda gubernatorstva Karafuto (1905-1945) [Monuments of history and culture of the Karafuto governorship period]. - Uzhno-Sakhalinsk: Sakhalinskaya oblastnaya tipographiya [Sakhalin regional printing house], 2015. - $167 \mathrm{p}$.

Samarin I. A. Sakhalinsky kirpich (seredina 19 - pervaya polovina 20 vv.): katalog kirpichey iz muzeev Sakhalinskoy oblasti I chastnykh sobraniy [Sakhalin brick (mid-XIX - first half of XX): catalogue of bricks from Sakhalin region museums and private collections]. - Uzhno-Sakhalinsk: Sakhalinskaya oblastnaya tipographiya [Sakhalin regional printing house], 2018. - $114 \mathrm{p}$.

Yankovky Y., Yankovsky V. Nenuni: Dalnevostochnaya odisseya [Nanuni: the far Eastern Odyssey]. - Vladivistok: Rubezh [Milestone], 2012. - 640 p. 